\title{
Factors Affecting Sectoral Employment in Nigeria during the Period of Growth (1981-2014)
}

\author{
Adetunji Adeniyi, PhD (Corresponding author) \\ Tunji Adeniyi and Associates Limited, Lagos, Nigeria \\ www.tunjiadeniyi.io
}

Tel: 234-(0)-805-700-0700Ｅ-mail: tunjiadeniyi@icloud.com

\author{
Received: February 13, 2021 Accepted: March 1, $2021 \quad$ Published: May 6, 2021 \\ doi:10.5296/ijld.v11i2.18613ＵRL: https://doi.org/10.5296/ijld.v11i2.18613
}

\begin{abstract}
The Nigerian economy was characterised with high levels of unemployment during the periods of substantial growth between 1981 and 2014. Various economists described the growth regime as "jobless". Sectoral differences were, also, observed with regard to their job absorptive capacities. Time series secondary data covering 1981 to 2014 on the rebased Gross Domestic Product (GDP) and sectoral Gross Value Added (GVA) at 2010 constant basic prices, employment, wage rate, inflation rate and interest rate were collected from the National Bureau of Statistics (NBS) and Central Bank of Nigeria (CBN). The variables were extracted from statutory publications of the institutions, collated and summarised into a table of data. The unit root test was carried out to test for stationarity of variables. The data was analysed using VECM at $\alpha \mathbf{0 . 0 5}$. The result shows that wage rate, inflation rate, and interest rate all affected employment negatively across sectors. Gross Value added affected employment positively in the non-agricultural sectors, but negatively in the agricultural sectors. Inter-sectoral linkages and dependences also peculiarly affected job creation positively or negatively.
\end{abstract}

Keywords: Economic growth, economic sectors, employment, unemployment, gross value added

\section{Introduction}

One of the major socio-economic challenges facing Nigeria today is very high and rising unemployment that seems to defy all the policies devised by government to address the malaise. Economists have postulated in literature that economic growth generates employment. It is against this back-drop that it was expected that the growth regime of 1981 to 2014 should have helped to reduce unemployment by generating a more than 
commensurate employment.

Economic literature, however, acknowledges the advent of "jobless growth" whereby unemployment co-exists with economic growth.

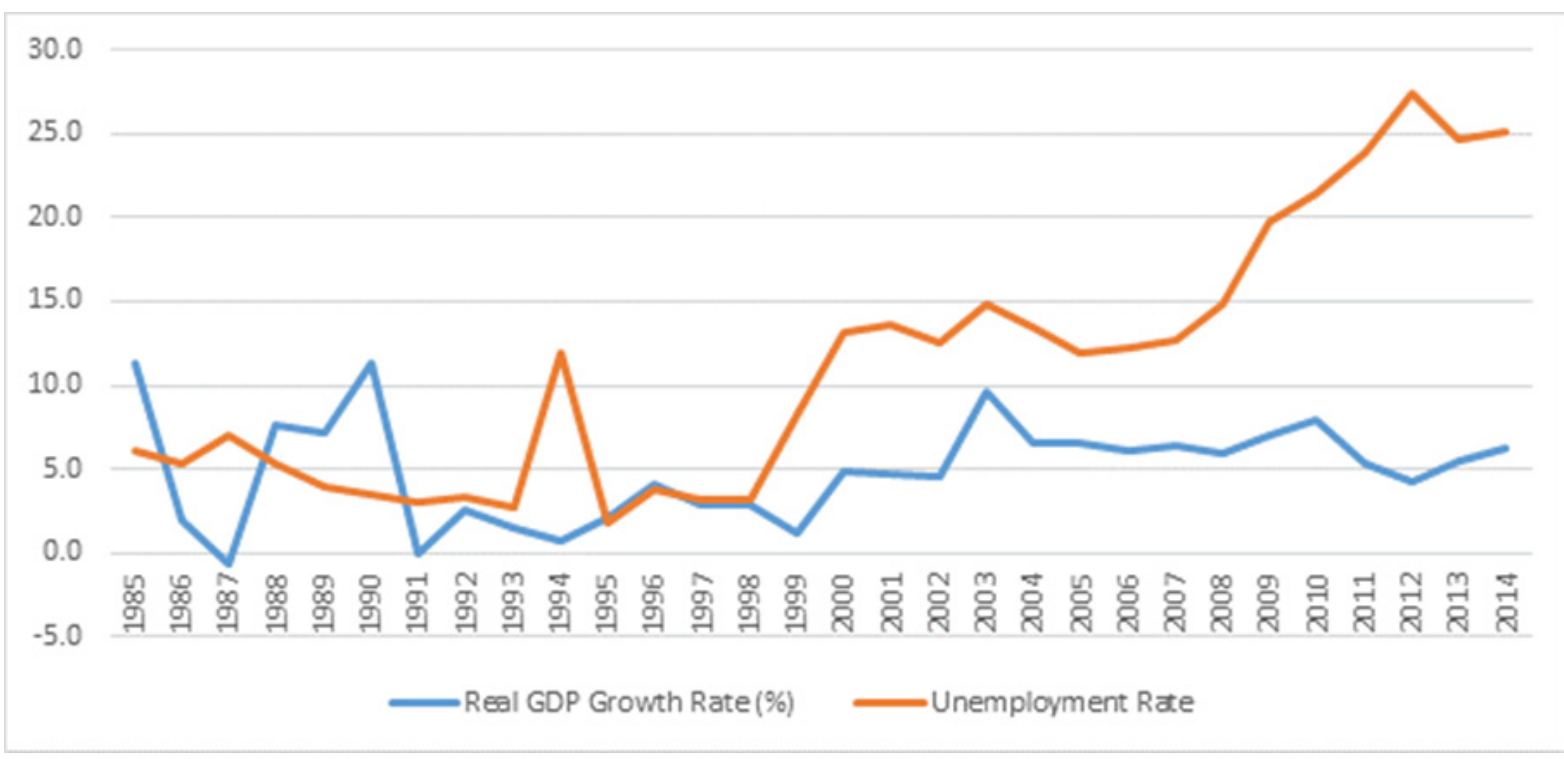

Figure 1. Rising Unemployment Co-existing with Economic Growth

Source: Author's analysis of data collected from the National Bureau of Statistics

According to the National Bureau of Statistics (2015) the rate of unemployment was 8.2 per cent by the end of the second quarter of 2015, despite the growth performance of the preceding years. The situation, which has further deteriorated due to subsequent economic decline, was recently accentuated by the outbreak of the COVID-19 pandemic, as unemployment rose to a record high of 27 per cent by the second quarter of 2020 (FGN, 2017; FGN, 2020; and, NBS, 2020).

Adeniyi, 2019, observed that, in the period of economic growth under investigation, relative employment growth differed among economic sectors. This was consistent with Ajakaiye, et al., 2016. Then, the appropriate research question is: what factors affect sectoral employment in Nigeria during the period of growth? The objective of this study, therefore, is to ascertain the factors affecting sectoral employment in Nigeria during the period of growth. This will enable policy makers to fashion out sector-specific employment stimulating growth strategies.

\section{Literature Review}

According to Ajakaiye et al, 2016, Agriculture is the lead contributor to employment in Nigeria, accounting for more than $50 \%$ of employment. However, they reported an increasing marginal shift from the Agricultural sector in both absolute figures and the proportion of people working in the sector. Although, overall employment in Manufacturing, just as in Agriculture, also fell significantly between 2005 and 2014, Agriculture consistently had the 


\section{Macrothink}

International Journal of Learning and Development

ISSN 2164-4063

2021, Vol. 11, No. 2

largest negative contribution to the change in employment rate in Nigeria between 2005 and 2014. During the period, only Mining and Services sectors registered absolute employment growth. Employment contribution, however, shrank in all sectors, except in the services sector, where GDP contributions also more than doubled (Ajakaiye et al, 2016). According to Adeniyi (2019) employment is transitioning from production in the real sectors of Agriculture and Manufacturing to the Services sectors in Administration and Social Services, and Trade and Services sectors.

\section{Theoretical Framework}

The national output of an economy is produced by combining labour input (demand for labor) with other factors of production. The demand function for labor can be derived by assuming a constant elasticity of substitution (CES) production function and solving the marginal product of labor (MPL) equation for the labor input variable (Mkhize, 2015; Adeniyi, 2021) as follows: -

$$
\text { GVAt }=\mathrm{A}\{\alpha \mathrm{K}-\rho+(1-\alpha) \mathrm{E}-\rho\}-\eta /-\rho
$$

where, is

$\mathrm{Kt}=$ Capital (input) in year $\mathrm{t}$; $\mathrm{Et}=$ Employment/labor (input) in year $\mathrm{t}$.

$\mathrm{A}=$ Efficiency parameter; $\mathrm{A}>0$

$\eta=$ Returns to scale parameter; $\eta>0$

$\alpha=$ Distribution parameter; $0<\alpha<1$

$\rho=$ Extent of substitution (between $\mathrm{K}$ and E) parameter, $\rho>-1$, and related to elasticity of substitution; $\sigma=1 / 1+\rho$

The derivative of labor (i.e. marginal product of labor (MPL)) from Equation (1) can be written as:

$$
\mathrm{dGVA} / \mathrm{dE}=\eta(1-\alpha) / \mathrm{A} \rho / \eta \cdot \mathrm{GVA}(1+\rho) / \eta / \mathrm{E} \rho+1
$$

The above MPL expression is solved for the Et input variable in order to derive the empirical labor (employment) demand function:

$\eta(1-\alpha) / A \rho / \eta \cdot G V A(1+\rho) / \eta=$ Et $\rho+1$

[9]

$[\eta(1-\alpha) / A \rho / \eta \cdot G V A(1+\rho) / \eta] 1 / \rho+1=E t$

$E t=[\eta(1-\alpha) / A \rho / \eta \cdot G V A(1+\rho) / \eta] 1 / \rho+1$

$=[\eta(1-\alpha) / A \rho / \eta] 1 / \rho+1 . \operatorname{GVA}(1+\rho / \eta)(1 / \rho+1)$

$$
\mathrm{Et}=\beta 0 \mathrm{GVA} \beta 1
$$

where, 
$\beta 0=[\eta(1-\alpha) / A \rho / \eta] 1 / \rho+1$

$\beta 1=(1+\rho / \eta)(1 / \rho+1)$

$\beta 1=1+\rho / \eta \cdot \sigma$

$\sigma($ elasticity of substitution $)=1 / \rho+1$. obtain the following employment function:

$$
\ln \mathrm{Et}=\ln \beta 0+\beta 1 \ln \mathrm{GVAt}
$$

\section{Methodology}

The study investigated the factors that affected employment during the economic growth regime in Nigeria between 1981 and 2014. The secondary data used for the study were collected from the Central Bank of Nigeria (CBN), and the National Bureau of Statistics (NBS).

The variables collected, collated, analysed and presented were the figures of Gross Domestic Product (GDP), Sectoral Gross Value Added (sectoral GDP), aggregate employment, sectoral employment, minimum wage rates, weighted average prime lending rates and inflation rates from 1981 to 2014. Estimation methodology of elasticity of employment, in deference to Ajilore and Yinusa (2011); Mkhize (2015); and, Adeniyi (2021) was used to analyse the data. Specifically, we used the Vector Error Correction Model (VECM).

In order to estimate the sectoral employment elasticities of the main sectors of the economy and the elasticities of employment with respect to wage rate, inflation and user cost of capital in the economy during the period under review, a double-log linear regression equation was constructed for the parameters as follows:

$$
\ln L_{t}=\beta_{0}-\beta_{1} \ln W_{t}+\beta_{2} \ln r_{t}+\beta_{3} \ln G V A_{t}+\beta_{4} \ln \pi_{t}+T_{t}+\varepsilon_{t}
$$

where, $\mathrm{t}=1, \ldots, \mathrm{n}$ years. The dependent variable, $L_{t}$, represents aggregate employment (formal and informal, public and private) in thousands of persons in the specific economic sectors, in year $t$.

The main economic sectors in Nigeria considered for employment during the period under review are (NBS, 2015):

EMP_AGRI= Employment in the Agriculture sector in year $\mathrm{t}$.

EMP_MIN\&QUA= Employment in the Mining and Quarrying sector in year t.

EMP_MAN=Employment in the Manufacturing sector in year $\mathrm{t}$.

EMP_CONST $=$ Employment in the Construction sector in year $\mathrm{t}$.

EMP_ADM\&SOC $=$ Employment in the Administration and Social Services sector in year $\mathrm{t}$.

EMP_TRA\&SER= Employment in Trade and Services sector in year $\mathrm{t}$. 


\section{Macrothink}

The exogenous variables are:

$\mathrm{W}_{t}=$ minimum wage rate in time $\mathrm{t}$, measured in thousand Naira.

$\mathrm{r}_{t}=$ is the user cost of capital in time $\mathrm{t}$, represented by the weighted average prime lending rate in the economy.

$\pi_{\mathrm{t}}=$ inflation rate in time $\mathrm{t}$.

$\mathrm{GVA}_{t}=$ sector specific GVA in constant 2010 basic prices.

Similarly, the major economic sectors considered for GVA in Nigeria during the period under review are (Adeniyi, 2021):

GVA_AGRI= Gross Value Added in the Agriculture sector in year t.

GVA_MIN\&QUA = Gross Value Added in the Mining and Quarrying sector in year t.

GVA_MAN= Gross Value Added in the Manufacturing sector in year t.

GVA_CONST $=$ Gross Value Added in the Construction sector in year t.

GVA_ADM\&SOC $=$ Gross Value Added in the Administration and Social Services sector in year $\mathrm{t}$.

GVA_TRA\&SER= Gross Value Added in Trade and Services sector in year $\mathrm{t}$.

TIME $\left(T_{t}\right)=$ yearly time trend variable, where $t=1$ is year ended December, 1981 and $t=34$ is year ended December, 2014.

$\varepsilon_{\mathrm{t}}=$ error term.

The function to be analysed in this study is as follows (Adeniyi, 2021):

$$
L_{t}=f\left(W_{t}, r_{t}, \pi_{t} G V A_{-} A G R I_{t}, G V A_{-} M I N I N G_{t}, G V A_{-} M A N_{t}, G V A_{-} C O N S T_{t}, G V A_{-} A D M I N_{t} G V A_{-} T R A S E R V_{t}\right)
$$

From the model, the equations to analyse are: -

1) $\mathrm{AGG}_{-} \mathrm{EMP}=\mathrm{f}\left(\mathrm{GDP} t, W_{t}, r_{t}, \pi_{t}\right)$

2) $\quad \mathrm{EMP} \_\mathrm{AGRIC}=\mathrm{f}\left(\mathrm{GVA} \_\right.$AGRI $\left., W_{t}, r_{t}, \pi_{t}\right)$

3) EMP_MIN\&QUA $=\mathrm{f}\left(\mathrm{GVA} \_\mathrm{MIN} \& \mathrm{QUA} t, W_{t}, r_{t}, \pi_{t}\right)$...

4) $\mathrm{EMP} \_\mathrm{MANU}=\mathrm{f}\left(\mathrm{GVA} \_\mathrm{MANU}, W_{t}, r_{t}, \pi_{t}\right)$...

5) $\mathrm{EMP}_{-} \mathrm{CONST}=\mathrm{f}\left(\mathrm{GVA}_{-} \mathrm{CONST}_{t}, W_{t}, r_{t}, \pi_{t}\right)$ 


\section{NI Macrothink}

6) $\mathrm{EMP} \_\mathrm{ADM} \& \mathrm{SOC}=\mathrm{f}\left(\mathrm{GVA}{ }_{-} \mathrm{ADM} \mathrm{SOC}_{t}, W_{t}, r_{t}, \pi_{t}\right)$

7) EMP_TRA\&SER$=\mathrm{f}\left(\mathrm{GVA}+\mathrm{TRASER}_{t}, W_{t}, r_{t}, \pi_{t}\right)$

Where:

$$
\begin{aligned}
& W_{t}=\text { Minimum Wage Rate in year } \mathrm{t} \\
& r_{t}=\text { WAPLR in year } \mathrm{t} \\
& \pi_{t}=\text { inflation rate in year } \mathrm{t}
\end{aligned}
$$

The above model postulates that employment of persons will vary with macroeconomic variables, and that employment decisions by economic units are a function of previous year's information.

\subsection{Description of the Variables}

Gross Domestic Product (GDP): Gross Domestic Product (GDP) is the value of all the final goods and services produced by a country over a specified period, usually one year (NBS, 2014). Gross Value Added (GVA) is the value of goods and services produced in a sector. It is the output of the sector less intermediate consumption in that sector. In this study, these variables were obtained from the Nigerian National Bureau of Statistics (NBS). Yearly GDP and GVA series at 2010 constant basic prices were collected from NBS for the period 1981 to 2014. The series, which were in billions of Naira, were produced after the GDP rebasing exercise of 2014 which used 2010 as the base year and covered the 46 (up from 33) reclassified economic activity sub-sectors of the Nigerian economy (Adeniyi, 2021).

Time trend: In a time-series analysis, time is a variable as the other variables and the relationships among them changes or stabilises over time. The lagging approach employed in the analysis took care of the time trend in determining /explaining employment level in the economy (Adeniyi, 2021).

Wages: Wage series were not available from the National Bureau of Statistics and other relevant organisations. Furthermore, NBS has not produced the re-based GDP using expenditure approach as of the time of this study. The latter would have been decomposed to obtain the wage component.

Although there are various concepts of wages we adopted the minimum wage in the economy for the following reasons which outweigh its limited variability since it does not change annually: It is more relevant to policy making; more determinable with exactitude; better known to everybody; more relevant to the economic strata where employment expansion is most desired, more relevant in determining the minimum financial welfare in the economy, etc. According to ILO (1970) the minimum wage represents the amount of compensation that 
an employer is required to pay wage earners for the work performed during a giving period, which cannot be reduced by collective agreement or by an individual contract. Minimum wage is, therefore, the lowest compensation that employers may legitimately pay to workers. This implies that it is the price floor below which a worker may not legally sell his labour services (Adeniyi, 2021).

Furthermore, recent debates among the three tiers of Government in Nigeria, the Labour Union, the Legislators, Non-Governmental Organisations, and Social Commentators on minimum wage did not only support this choice but seems to have heavy impact on the ethnic - or geo - political organisation, reorganisation and/or viability of the federating units of Nigeria (Eme \& Ugwu, 2011; Ajimotokan and Obi, 2016; Buhari, 2016). It is more relevant in employment decision making particularly in the government sector that is very wage elastic, but expected to be employment intensive. For example, according to the Senate of the Federal Republic of Nigeria in its plenary of July 21, 2016, '27 states of the federation can no longer pay the salary of their workers.'

Other wage concepts are: average wages in the public sector, average wages in the private sector, average wages in the junior staff category and average salaries and emoluments of senior staff categories both in the public and private sectors (NECA, 2003; and, Adeniyi, 2021). For this study, minimum wage change history was obtained from NBS and from this; the minimum wage series was generated.

Interest rate: There are various concepts of the user cost of capital (Ajilore and Yinusa, 2011 Mkhize, 2015). This study used the Weighted Average Prime Lending Rate (WAPLR) of banks operating in the economy during the period, because it is more relevant considering that it affects every economic borrowing decision in the economy. It is subject to regular (weekly) professional determination and reviews at the Assets and Liability Management Committees (ALCOs) of all the banks operating in the economy. Besides, the determination of WAPLR also bears reference to the weighted average cost of generating loanable funds by lenders in the economy. Long-term lending, available only to prime bank customers, is consummated at around the Prime Lending Rate (CBN, 2015; and, Adeniyi, 2021).

Unemployment Rate: The data of unemployment rate was collected at the National Bureau of Statistics (NBS).

Inflation Rates: Annual Inflation Rates data were also collected from the National Bureau of Statistics.

GDP: Annual GDP and GVA for the economy and for the sectors, respectively, were collected from the national Bureau of Statistics.

\subsection{Unit Root Test}

Time series data are most useful when they do not contain noise or unit root problems. However, frequently associated with time series data is the problem of noise. Consequently, it is necessary to test for and remove unit roots when and if they exist in any series. If they do, the noise must first be removed before proceeding with analysis in other that the results are 
not spurious, in other words, so that we can rely on the results for interpretation.

When there is no unit root or the noise has been removed, the series is said to be stationary. Several tests of stationarity have been developed to examine whether a series is stationary or non-stationary. If the series under analysis is stationary at level, this implies that the series contains no noise. Therefore, the series is said to be $\mathrm{I}(0)$. However, if the series being analysed is non-stationary in its level form, but stationary in the first difference form, then, it is said to be integrated of order 1 or I(1). Most time series can be classified as being integrated of order $d, \mathrm{I}(d)$. This means that the series must be differenced $d$ times to become stationary. The most common test of the stationarity of a time series is the Augmented Dickey-Fuller (ADF) test proposed by Engle and Granger in 1987 as follows (Adeniyi, 2021):

$$
\Delta \boldsymbol{Y}_{\boldsymbol{t}}=\boldsymbol{\beta}_{\mathbf{1}}+\boldsymbol{\beta}_{2 t}+\boldsymbol{\delta} \boldsymbol{Y}_{t-1}+\sum_{i=1}^{m} \alpha_{i} \Delta Y_{t-i}+\varepsilon_{t}
$$

where $Y_{t}$ is the relevant time series, $t$ is time trend, $\varepsilon_{t}$ a white noise error term ; where

$$
\Delta Y_{t-1}=\left(Y_{t-1}-Y_{t-2}\right), \Delta Y_{t-2}=\left(Y_{t-2}-Y_{t-3}\right)
$$

The hypothesis of the ADF test will be specified as follows:

Null hypothesis: Ho: $\beta=0$

Alternative hypothesis: $\mathrm{H}_{1}: \beta<0$

If the null hypothesis is not rejected, then the series is non-stationary, but if it is rejected, it means the series is stationary or $\mathrm{I}(0)$. A time series is stationary when the process by which the data is generated is the same over time. That is, the series' mean, variance and covariance with lagged values of itself should not change with time. (Hansen and King, 1996; Mkhize, 2015). According to Mkhize, (2015) ADF test tends to over-reject the null hypothesis when using too few lags and to reduce the degrees of freedom when there are too many lags. Song and Witt (2000) in their study of tourism demand modelling and forecasting, justified the importance of appropriate lag length for time series data. In determining the appropriate lag length for the ADF test in the study, Schwarz Information Criterion was used.

\subsection{Cointegration Test}

According to Stock and Watson (2017) when variables individually non-stationary are co-integrated, two (or more) variables may have common underlying stochastic trends along which they move together on a non-stationary path. For simple instances of few variables and one co-integrating relationship, an error-correction model (ECM) is the appropriate econometric specification. In this model, the equation is differenced and an error-correction term estimating the previous period's ( $\mathrm{t}-1)$ deviation from long-run equilibrium is included.

The most common tests to investigate the number of common trends among the series in a VAR/VEC were developed and proposed by Johansen (1995). The approach is very similar to testing for unit roots in the polynomial representing an Auto Regression (AR) process. If we 
have $n$ I (1) variables that are modelled jointly in a dynamic system, there can be up to $n-1$ co-integrating relationships linking them. Stock and Watson (2017) thought of each co-integrating relationship as a common trend interconnecting some or all the series in the system. The co-integrating rank of the system is the number of such common trends, or the number of co-integrating relationships (Adeniyi, 2021).

To select the co-integrating rank $r$, a sequence of tests was performed. First, the null hypothesis of $\mathrm{r}=0$ against $\mathrm{r} \geq 1$ to investigate if there is at least one co-integrating relationship was tested. If and when $r=0$ is not rejected, then it was concluded that there were no common trends among the series, in which case, a VEC model is not needed. VAR is then simply used in the differences of the series.

If $r=0$ is rejected at the initial stage, then at least some of the series are co-integrated. Then, the number of co-integrating relationships is determined. The second step is to test the null hypothesis that $r \leq 1$ against $r \geq 2$. If the hypothesis of no more than one common trend is not rejected, then we estimate a VEC system with one co-integrating relationship.

If the hypothesis that $r \leq 1$ is rejected, then the hypothesis $r \leq 2$ against $r \geq 3$ is tested, and so on. $r$ is chosen to be the smallest value at which the null hypothesis that there are no additional co-integrating relationships is not rejected.

Johansen proposed many relevant tests that can be employed at each stage. The most common is the trace statistic, which was used in this study. The Stata command vecrank prints the trace statistic or, alternatively, the maximum-eigenvalue statistic.

\subsection{Vector Error Correction Model}

Vector error correction model (VECM) is the regression that takes into consideration the correction of the noise/unit root in the model as well as estimating the part of the noise that is being removed at each short run. (Stock and Watson, 2017). The software used for the regression analysis was Stata.

\subsection{A Priori Expectations}

The signs expected for the coefficients in the model are as follows:

$\mathbf{W}_{\boldsymbol{t}}$ : negative. If and when the percentage change in nominal wages increases, it reduces employers effective demand for labour, given a constant budget constraint and vice-versa. (Dokpe 2001; Soto 2009; Baah-Boateng, 2013; and, Adeniyi, 2021).

$\mathbf{r}_{t}$ : positive or negative. If the interest rate increases, the demand by employers for capital decreases and the demand for consumer goods and services also decreases. The reduced demand for capital (that would become relatively more expensive) will reduce labour productivity and the depressed demand for consumer goods and services will decrease the derived demand for labour, vice versa. In these situations, employment would move in opposite directions to long term interest rates. However, in some industries capital may be a substitute for labour. In that wise, an increase in long term interest rates may depress the demand for capital and enhance the demand for labour, the substitute, vice versa. 


\section{Macrothink}

Consequently, long term interest rates would be a positive correlate of employment. (Malunda, 2012; Nangale, 2012; Baah-Boateng, 2013; Mkhize, 2015; and, Adeniyi, 2021).

$\pi_{\mathrm{t}}$ : positive or negative. The effect of inflation rate is expected to either be positive or negative. When and if the rate of inflation increases, the marginal revenue products of labour increases. As a consequence, there is an increase in the demand for labour by employers. On the other hand, an increase in inflation rate may reduce consumer demand for goods and services, thereby depressing the derived demand for labour as a factor of production. (Mkhize, 2015).

GVA $_{t}$ : positive. The growth of sectoral real GVA will lead to expanded derived demand for labour because employers will view real sector output growth as an indication of future expansion in demand for consumer final goods and services (Soto, 2009; Sodipe and Ogunrinola, 2011; Temitope, 2013; Mkhize, 2015; and, Adeniyi, 2021).

In order to make the model very useful for the analysis, equation (10) is log-linearised. The logarithmic functional form ensures that $\beta_{i}$ can be interpreted as elasticities (Koop, 2005 and Felipe and McCombie, 2015), where $\beta_{2}$ is the elasticity of employment with respect to user cost of capital, while holding all other things constant ceteris paribus. In the same manner, also $\beta_{3}$ is the elasticity of employment with respect to output. It estimates the proportional change in the number of labour employed for a proportional change in sectoral GVA, holding other factors constant, ceteris paribus. Consequently, a positive elasticity coefficient of 0.25 , for example, indicates that a percentage increase in GVA is associated with a quarter of a percentage increase in the number of people employed. The employment elasticity coefficients that will be calculated from the equation above imply that employment is a direct correlate of output (Soto, 2009; Sodipe and Ogunrinola, 2011; Temitope, 2013; and, Adeniyi, 2021). Consequently, the elasticity coefficients estimated for individual economic sectors are suggestive of the correlation between the number of persons employed and gross value added.

\section{Findings and Discussions}

Indicated in figure 1 below are the extracts from the VECM analysis as shown in Tables 1 to 5. A discussion of the factors that affected employment during the period of growth between 1981 and 2014 is presented below. 


\title{
Extracts from VECM
}

\author{
(+)E_NonAgri-2/ GVA \\ NonAgri-2 \\ (-) E_Agri-2/ \\ GVA_Agri-1/ \\ WageRate-1 \\ (+) E_Admin-1/ \\ E_Mining-1 \\ (-) E_Agric-1/ \\ E_Man'g-2/ E_Const-1/ \\ Inflation-1/ WAPLR-1
}

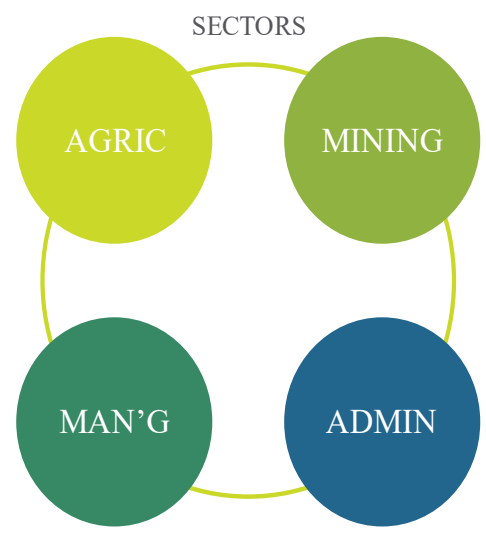

(+) GVA_Man'g-1

(-) GVA_Agri-1/

GVA_Const - 2/

WAPLR - 1

(+) E_Agri - 2/

GVA_Min - 1

(-) E_Man'g - 1/

GVA_Const - 1

Figure 1. VECM extracts (Factors that affected sectoral employment between 1981 and 2014) 


\section{Macrothink}

International Journal of Learning and Development ISSN 2164-4063

Table 1. Employment in agriculture sector

\begin{tabular}{|c|c|c|c|c|c|c|}
\hline & Scenario1 & Scenario2 & Scenario3 & Scenario4 & Scenario5 & Scenario6 \\
\hline & Coef. (z) & Coef.(z) & Coef.(z) & Coef.(z) & Coef.(z) & Coef.(z) \\
\hline $\mathrm{Ce} 1$ & $2.45(1.34)$ & $0.128(2.99) * * *$ & $-3.135(-0.79)$ & $-1.252(-3.34) * * *$ & - & $-0.0611(-0.39)$ \\
\hline $\mathrm{Ce} 2$ & $-2.07(-2.13) * *$ & $-0.114(-2.62) * * *$ & $3.328(1.11)$ & $-0.986(-3.72) * * *$ & - & $0.009(0.33)$ \\
\hline $\mathrm{Ce} 3$ & $-.497(-0.65)$ & $0.275(2.95) * * *$ & $-0.416(-1.26)$ & $2.133(3.56) * * *$ & - & $0.141(0.43)$ \\
\hline $\mathrm{Ce} 4$ & & $-0.119(-3.08) * * *$ & - & - & - & - \\
\hline Employment Agriculture(-1) & $0.11(0.08)$ & $-0.705(-2.26)^{* *}$ & $-2.678(-1.24)$ & - & - & - \\
\hline Employment Agriculture(-2) & $-1.94(-2.08) * *$ & $0.156(0.36)$ & $-0.497(-0.49)$ & - & - & $-0.171(-0.3)$ \\
\hline Employment Mining(-1) & - & $-0.449(-1.22)$ & - & - & - & $-0.29(-0.73)$ \\
\hline Employment Mining(-2) & - & $-0.309(-0.74)$ & - & - & - & $-0.038(-0.06)$ \\
\hline Employment Manufacturing (-1) & - & $-0.112(-0.67)$ & - & - & - & $-0.734(-1.33)$ \\
\hline Employment Manufacturing (-2) & - & $-0.354(-1.97) * *$ & - & - & - & $-0.006(-0.02)$ \\
\hline Employment Construction(-1) & - & $0.081(0.17)$ & - & - & - & $-0.012(-0.03)$ \\
\hline Employment Construction(-2) & - & $-0.649(-1.54)$ & - & - & - & $-0.122(-0.16)$ \\
\hline Employment Admin(-1) & - & $-0.027(-0.07)$ & - & - & - & $0.074(0.12)$ \\
\hline Employment Admin(-2) & - & $0.913(2.30)^{* *}$ & - & - & - & $-0.06(-0.56)$ \\
\hline Employment Trade & - & - & - & - & - & $0.051(0.62)$ \\
\hline
\end{tabular}




\begin{tabular}{|c|c|c|c|c|c|c|}
\hline $\begin{array}{l}\text { Macrothink } \\
\text { Institute }\end{array}$ & & & & \multicolumn{3}{|c|}{$\begin{array}{r}\text { International Journal of Learning and Development } \\
\text { ISSN 2164-4063 } \\
\text { 2021, Vol. 11, No. } 2 \\
\end{array}$} \\
\hline Employment Non-agric(-1) & $-0.25(-0.35)$ & - & - & - & - & - \\
\hline Employment Non-agric(-2) & $1.15(2.23)^{* *}$ & - & - & - & - & - \\
\hline GVA Agriculture(-1) & $-0.13(-2.10)^{* *}$ & $-0.0653(-1.98)^{* *}$ & - & - & - & - \\
\hline GVA Agriculture(-2) & $0.018(0.34)$ & $0.0356(0.96)$ & - & $1.18(3.75)^{* * *}$ & - & $-0.06(-0.56)$ \\
\hline GVA Mining(-1) & - & $0.115(1.98)^{* *}$ & $1.219(1.23)$ & $0.561(2.29)^{* *}$ & - & $0.051(0.62)$ \\
\hline GVA Mining(-2) & - & $0.126(3.54)^{* * *}$ & $0.843(0.90)$ & $-0.184(-0.51)$ & - & $0.014(0.17)$ \\
\hline GVA Manufacturing $(-1)$ & - & $-0.022(-0.6)$ & $0.089(0.09)$ & $-0.205(-0.8)$ & - & $0.107(1.26)$ \\
\hline GVA Manufacturing (-2) & - & $-0.069(-1.91)^{*}$ & $-0.332(-0.55)$ & $-0.252(-0.56)$ & - & $-0.0005(-0.01)$ \\
\hline GVA Construction(-1) & - & $-0.003(-0.10)$ & $-2.303(-0.94)$ & $-0.538(-2.82)^{* * *}$ & - & $-0.003(0.09)$ \\
\hline GVA Construction(-2) & - & $-0.14(-2.80)^{* * *}$ & $-1.589(-0.90)$ & $0.757(3.77) * * *$ & - & $-0.016(-0.18)$ \\
\hline GVA Admin $(-1)$ & - & $0.64(3.83)^{* * *}$ & $0.974(0.92)$ & $0.506(2.33) * *$ & - & $-0.023(-0.46)$ \\
\hline GVA Admin (-2) & - & $0.48(4.31)^{* * *}$ & $1.492(1.34)$ & $\begin{array}{l}-1.405(-2.61) \\
* * *\end{array}$ & - & $0.177(0.54)$ \\
\hline GVA Trade & - & - & - & $\begin{array}{l}-2.669(-4.23) \\
* * *\end{array}$ & - & $0.259(0.9)$ \\
\hline GVA Non-agric(-1) & $0.085(0.70)$ & - & - & - & - & - \\
\hline GVA Non-agric(-2) & $0.39(2.59)^{* *}$ & - & - & - & - & - \\
\hline GDP & - & - & - & - & - & - \\
\hline Inflation Rate(-1) & $-0.002(-0.34)$ & - & $-0.008(-0.72)$ & - & - & - \\
\hline
\end{tabular}


Inflation Rate(-2)

WAPLR(Weighted

Lending Rate)(-1)

WAPLR(Weighted Average Prime

Lending Rate)(-2)

Minimum wage (-1)

Minimum wage (-2)

Constant

Average Prime

$0.008(1.21)$

International Journal of Learning and Development ISSN 2164-4063 2021, Vol. 11, No. 2

Source: Author's Analysis of Data collected from the National Bureau of Statistic

Table 2. Employment in mining and quarrying sector

\begin{tabular}{|l|l|l|l|l|l|l|l|}
\hline \multirow{2}{*}{ Ce1 } & Scenario1 & Scenario2 & Scenario3 & Scenario4 & Scenario5 & Scenario6 \\
\cline { 2 - 7 } Ce2 & Coef.(z) & Coef.(z) & Coef.(z) & Coef.(z) & Coef.(z) & Coef.(z) \\
Ce3 & - & $0.037(0.52)$ & $-1.911(-0.7)$ & $0.081(0.21)$ & - & $-0.138(-1.02)$ \\
Ce4 & - & $0.038(0.48)$ & $-1.395(-0.67)$ & $1.096(3.99)^{* * *}$ & - & $0.03(1.31)$ \\
Ce5 & - & $-0.114(-1.57)$ & $0.413(1.81)^{*}$ & $-1.624(-2.62)^{* * *}$ & - \\
Employment Agriculture(-1) & - & $0.056(0.36)$ & - & - & $0.173(0.61)$ \\
& - & $-0.065(-1.00)$ & - & - & - \\
\end{tabular}




\begin{tabular}{|c|c|c|c|c|c|c|}
\hline Employment Agriculture(-2) & - & $0.824(1.15)$ & $0.812(1.15)$ & - & - & $-0.563(0.1)$ \\
\hline Employment Mining(-1) & - & $0.096(0.16)$ & $-0.603(-0.88)$ & - & - & $0.159(0.27)$ \\
\hline Employment Mining(-2) & - & $1.391(2)^{* *}$ & $-0.267(-0.41)$ & - & - & $0.305(0.64)$ \\
\hline Employment Manufacturing (-1) & - & $0.428(1.53)$ & $-1.07(-1.59)$ & - & - & $0.475(1.49)$ \\
\hline Employment Manufacturing (-2) & - & $0.268(0.89)$ & $-0.206(-0.50)$ & - & - & $-0.321(-0.8)$ \\
\hline Employment Construction(-1) & - & $0.198(0.25)$ & $-1.606(-0.94)$ & - & - & $0.62(0.93)$ \\
\hline Employment Construction(-2) & - & $-0.750(-1.07)$ & $-0.01(-0.01)$ & - & - & $-0.392(-0.75)$ \\
\hline Employment Admin(-1) & - & $0.155(0.23)$ & $0.708(0.96)$ & - & - & $-0.579(-1.02)$ \\
\hline Employment Admin(-2) & - & $1.272(1.91)^{*}$ & $0.151(0.2)$ & - & - & $0.743(1.37)$ \\
\hline Employment Trade & - & - & - & - & - & - \\
\hline Employment Non-agric(-1) & - & - & - & - & - & - \\
\hline Employment Non-agric(-2) & - & - & - & - & - & - \\
\hline GVA Agriculture(-1) & - & $0.022(0.41)$ & - & $-0.891(-2.73) * * *$ & - & $0.039(0.43)$ \\
\hline GVA Agriculture(-2) & - & $-0.104(-1.69)^{*}$ & - & $-0.285(-1.12)$ & - & $0.05(0.71)$ \\
\hline GVA Mining(-1) & - & $0.009(0.09)^{*}$ & - & $-0.069(-0.18)$ & - & $-0.154(-2.2) * *$ \\
\hline GVA Mining(-2) & - & $-0.043(-0.73)$ & - & $0.206(0.77)$ & - & $-0.064(-0.88)$ \\
\hline GVA Manufacturing (-1) & - & $-0.062(-1.04)$ & - & $1.241(2.67)^{* * *}$ & - & $0.064(1.79)$ \\
\hline GVA Manufacturing (-2) & - & $-0.076(-1.26)$ & - & $0.566(2.87)^{* * *}$ & - & $0.029(0.96)$ \\
\hline
\end{tabular}




\begin{tabular}{|c|c|c|c|c|c|c|}
\hline GVA Construction(-1) & - & $0.068(1.49)$ & - & $-0.166(-0.8)$ & - & $0.042(0.55)$ \\
\hline GVA Construction $(-2)$ & - & $-0.102(-1.2)$ & - & $-0.447(-1.99) * *$ & - & $0.079(1.8)$ \\
\hline GVA Admin (-1) & - & $-0.292(-1.04)$ & - & $0.909(1.63)$ & - & $0.152(0.54)$ \\
\hline GVA Admin (-2) & - & $-0.234(-1.27)$ & - & $0.571(0.87)$ & - & $-0.025(-0.1)$ \\
\hline GVA Trade & - & - & - & - & - & - \\
\hline GVA Non-agric (-1) & - & - & - & - & - & - \\
\hline GVA Non-agric (-2) & - & - & - & - & - & - \\
\hline $\operatorname{GDP}(-1)$ & - & - & - & - & - & - \\
\hline $\operatorname{GDP}(-2)$ & - & - & - & - & - & - \\
\hline Inflation Rate $(-1)$ & - & - & $-0.004(-0.51)$ & $0.0002(0.01)$ & - & $-0.007(-1.22)$ \\
\hline Inflation Rate(-2) & - & - & $-0.002(-0.46)$ & $0.007(0.36)$ & - & $-0.008(-1.36)$ \\
\hline WAPLR(Weighted Average Prime Lending Rate)(-1) & - & - & $-0.018(-0.65)$ & $-0.468(-2.82) * * *$ & - & - \\
\hline WAPLR(Weighted Average Prime Lending Rate)(-2) & - & - & $-0.002(-0.11)$ & $-0.166(-1.65)$ & - & - \\
\hline Minimum wage (-1) & - & - & $-0.009(-1.79)^{*}$ & $0.07(1.49)$ & - & - \\
\hline Minimum wage (-2) & - & - & $-0.006(-0.99)$ & $-0.021(-0.60)$ & - & - \\
\hline Constant & - & $0.012(0.53)$ & $-0.016(-1.21)$ & $-0.01(-0.21)$ & - & $-0.011(-0.98)$ \\
\hline
\end{tabular}

Source: Author's Analysis of Data collected from the National Bureau of Statistics 


\section{Macrothink}

International Journal of Learning and Development ISSN 2164-4063

Table 3.Employment in manufacturing sector

\begin{tabular}{|c|c|c|c|c|c|c|}
\hline & Scenariol & Scenario2 & Scenario3 & Scenario4 & Scenario5 & Scenario6 \\
\hline & Coef.(z) & Coef.(z) & Coef.(z) & Coef.(z) & Coef.(z) & Coef.(z) \\
\hline $\mathrm{Ce} 1$ & - & $0.306(0.83)$ & $-2.626(-0.12)^{* *}$ & $0.834(1.75)$ & - & $-0.101(-0.27)$ \\
\hline $\mathrm{Ce} 2$ & - & $0.329(0.8)$ & $20.739(2.45)^{* *}$ & $0.067(0.2)$ & - & $-0.03(-0.46)$ \\
\hline $\mathrm{Ce} 3$ & - & $-0.185(-0.49)$ & $-2.233(-2.40)^{* *}$ & $-1.127(-.49)$ & - & $0.44(0.55)$ \\
\hline $\mathrm{Ce} 4$ & - & $0.609(0.75)$ & - & - & - & - \\
\hline $\mathrm{Ce} 5$ & - & $-0.199(-0.59)$ & - & - & - & - \\
\hline Employment Agriculture(-1) & - & $0.74(0.27)$ & $-11.133(-1.82)^{*}$ & - & - & $2.361(1.71)$ \\
\hline Employment Agriculture(-2) & - & $3.17(0.85)$ & $0.300(0.10)$ & - & - & $1.594(1.66)$ \\
\hline Employment Mining(-1) & - & $-3.370(-1.06)$ & $5.134(1.83)^{*}$ & - & - & $0.453(0.28)$ \\
\hline Employment Mining(-2) & - & $-2.999(-0.83)$ & $2.441(0.92)$ & - & - & $-4.498(-3.37)^{* * *}$ \\
\hline Employment Manufacturing (-1) & - & $-2.331(-1.61)$ & $-3.337(-1.22)$ & - & - & $-2.521(-2.83)^{* * *}$ \\
\hline Employment Manufacturing (-2) & - & $-1.436(-0.92)$ & $-3.044(-1.79)^{*}$ & - & - & $-0.4(-0.36)$ \\
\hline Employment Construction(-1) & - & $-1.181(-0.29)$ & $-15.197(-2.20)^{* *}$ & - & - & $-2.914(-1.56)$ \\
\hline Employment Construction(-2) & - & $-1.003(-0.28)$ & $-7.667(-1.54)$ & - & - & $1.983(1.36)$ \\
\hline Employment Admin(-1) & - & $0.136(0.04)$ & $5.259(1.76)^{*}$ & - & - & $3.304(2.08)^{* *}$ \\
\hline Employment Admin(-2) & - & $1.243(0.36)$ & $5.378(1.71)^{*}$ & - & - & $-2.390(-1.58)$ \\
\hline
\end{tabular}




\begin{tabular}{|c|c|c|c|c|c|c|}
\hline $\begin{array}{l}\text { Macrothin } \\
\text { Institute }\end{array}$ & & & & \multicolumn{3}{|c|}{$\begin{array}{r}\text { International Journal of Learning and Development } \\
\text { ISSN 2164-4063 } \\
2021 \text {, Vol. 11, No. } 2 \\
\end{array}$} \\
\hline Employment Trade & - & - & - & - & - & - \\
\hline Employment Non-agric(-1) & - & - & - & - & - & - \\
\hline Employment Non-agric(-2) & - & - & - & - & - & - \\
\hline GVA Agriculture(-1) & - & $-0.151(-0.53)$ & - & $0.249(0.62)$ & - & $-0.501(-1.94)^{*}$ \\
\hline GVA Agriculture(-2) & - & $-0.275(-0.86)$ & - & $-0.252(-0.81)$ & - & $0.011(0.06)$ \\
\hline GVA Mining(-1) & - & $0.549(1.09)$ & - & $\begin{array}{l}1.352(2.94)^{*} \\
* *\end{array}$ & - & $0.228(1.16)$ \\
\hline GVA Mining(-2) & - & $0.317(1.03)$ & - & $\begin{array}{l}0.712(2.18)^{*} \\
*\end{array}$ & - & $0.446(2.17)^{* *}$ \\
\hline GVA Manufacturing (-1) & - & $-0.109(-0.35)$ & - & $\begin{array}{l}-1.197(-2.11) \\
* *\end{array}$ & - & $-0.110(-1.1)$ \\
\hline GVA Manufacturing (-2) & - & $-0.090(-0.29)$ & - & $\begin{array}{l}-1.036(-4.28) \\
* * *\end{array}$ & - & $-0.014(-0.17)$ \\
\hline GVA Construction(-1) & - & $0.010(0.04)$ & - & $0.334(1.31)$ & - & $-0.3(-1.38)$ \\
\hline GVA Construction $(-2)$ & - & $-0.379(-0.86)$ & - & $-0.241(-0.88)$ & - & $-0.061(-0.5)$ \\
\hline GVA Admin (-1) & - & $1.107(0.76)$ & - & $-0.723(-1.06)$ & - & $1.01(1.28)$ \\
\hline GVA Admin (-2) & - & $1.039(1.09)$ & - & $0.605(0.76)$ & - & $1.473(2.11)$ \\
\hline GVA Trade & - & - & - & - & - & - \\
\hline GVA Non-agric(-1) & - & - & - & - & - & - \\
\hline GVA Non-agric (-2) & - & - & - & - & - & - \\
\hline
\end{tabular}




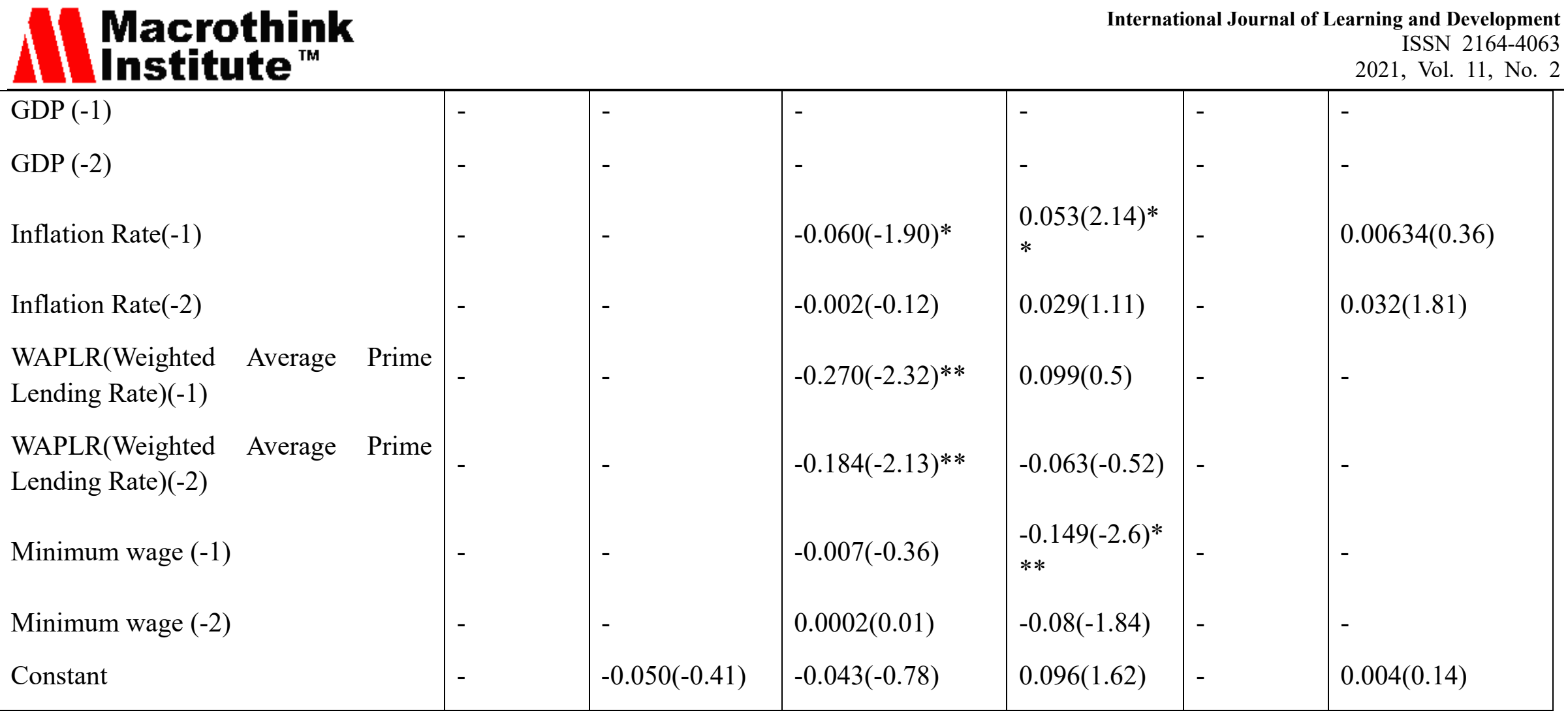

Source: Author's Analysis of Data collected from the National Bureau of Statistics 
Table 4. Employment in construction sector

\begin{tabular}{|c|c|c|c|c|c|c|}
\hline & Scenario1 & Scenario2 & Scenario3 & Scenario4 & Scenario5 & Scenario6 \\
\hline & Coef.(z) & Coef.(z) & Coef.(z) & Coef.(z) & Coef.(z) & Coef.(z) \\
\hline $\mathrm{Ce} 1$ & - & $0.079(0.74)$ & $2.136(0.79)$ & $0.790(2.94) * * *$ & - & $-0.208(-1.26)$ \\
\hline $\mathrm{Ce} 2$ & - & $0.108(0.92)$ & $-2.761(-1.34)$ & $-0.104(-0.55)$ & - & $0.04(1.4)$ \\
\hline $\mathrm{Ce} 3$ & - & $-0.153(-1.41)$ & $0.372(1.67)$ & $-0.194(-0.45)$ & - & $0.308(0.89)$ \\
\hline $\mathrm{Ce} 4$ & - & $0.234(1.01)$ & - & - & - & - \\
\hline $\mathrm{Ce} 5$ & - & $-0.160(-1.65)$ & - & - & - & - \\
\hline Employment Agriculture(-1) & - & $0.483(0.62)$ & $1.473(0.99)$ & - & - & $0.163(0.27)$ \\
\hline Employment Agriculture(-2) & - & $0.784(0.73)$ & $-0.058(-0.08)$ & - & - & $-0.620(-1.49)$ \\
\hline Employment Mining(-1) & - & $0.874(0.95)$ & $-0.188(-0.28)$ & - & - & $0.866(1.22)$ \\
\hline Employment Mining(-2) & - & $2.049(1.98)^{* *}$ & $-0.610(-0.95)$ & - & - & $0.898(1.55)$ \\
\hline Employment Manufacturing (-1) & - & $0.054(0.13)$ & $0.273(0.41)$ & - & - & $0.155(0.4)$ \\
\hline Employment Manufacturing (-2) & - & $-0.09(-0.22)$ & $0.561(1.36)$ & - & - & $-0.42(-0.86)$ \\
\hline Employment Construction(-1) & - & $-0.197(-0.17)$ & $1.682(1)$ & - & - & $0.225(0.28)$ \\
\hline Employment Construction(-2) & - & $-1.280(-1.22)$ & $0.959(0.79)$ & - & - & $-0.734(-1.15)$ \\
\hline Employment Admin(-1) & - & $0.119(0.12)$ & $-0.192(-0.26)$ & - & - & $-0.422(-0.61)$ \\
\hline Employment Admin(-2) & - & $1.767(1.78)$ & $-0.374(-0.49)$ & - & - & $0.976(1.01)$ \\
\hline
\end{tabular}




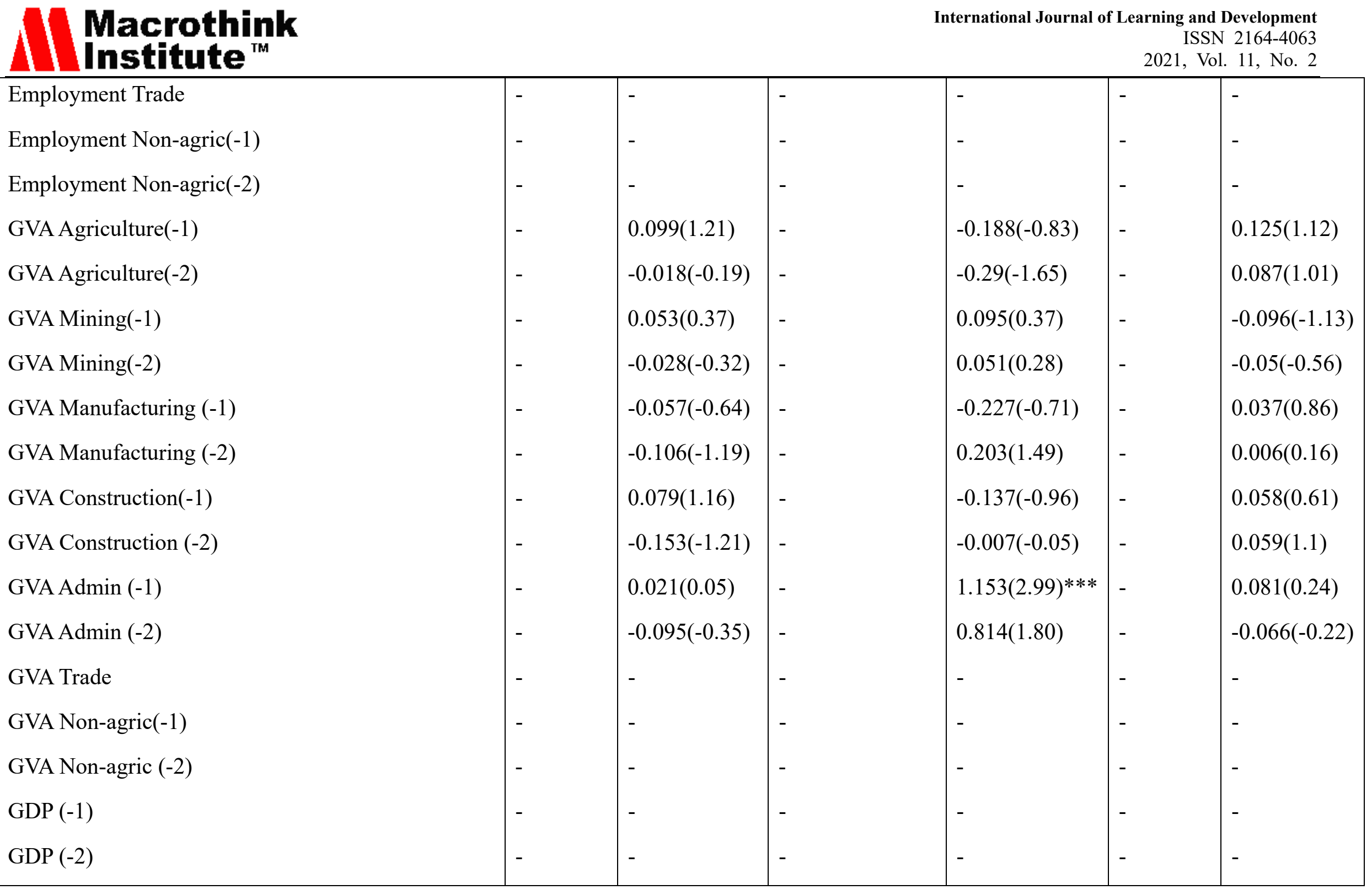




\section{MInstitute ${ }^{\text {Mit }}$}

Inflation Rate(-2)

WAPLR(Weighted Average Prime Lending Rate)(-1)

WAPLR(Weighted Average Prime Lending Rate)(-2)

Minimum wage (-1)

Minimum wage (-2)

Constant

International Journal of Learning and Development

ISSN 2164-4063

2021, Vol. 11, No. 2

\begin{tabular}{l|l|l|l|l|}
- & $0.006(-0.78)$ & $0.006(0.49)$ & - & $-0.008(-1.03)$ \\
- & $0.002(0.59)$ & $-0.009(-0.62)$ & - & $-0.009(-1.19)$ \\
- & $0.022(0.79)$ & $0.055(0.48)$ & - & - \\
- & $0.02(0.97)$ & $0.069(0.99)$ & - & - \\
- & $-0.015(-2.98) * * *$ & $-0.029(-0.92)$ & - & - \\
- & $-0.0007(-0.11)$ & $-0.010(-0.43)$ & - & $-0.007(-0.53)$ \\
$0.031(0.89)$ & $0.009(0.73)$ & $-0.025(-0.75)$ & - & - \\
\hline
\end{tabular}

Source: Author's Analysis of Data collected from the National Bureau of Statistics.

Table 5. Employment in administration and social services sector

\begin{tabular}{|c|c|c|c|c|c|c|}
\hline & Scenario1 & Scenario2 & Scenario3 & Scenario4 & Scenario5 & Scenario6 \\
\hline & Coef.(z) & Coef.(z) & Coef.(z) & Coef.(z) & Coef.(z) & Coef.(z) \\
\hline $\mathrm{Ce} 1$ & - & $0.308(2.08)^{* *}$ & $-6.349(-1.31)$ & $-0.302(-1.04)$ & - & $-0.241(-0.98)$ \\
\hline $\mathrm{Ce} 2$ & - & $0.359(2.18)^{* *}$ & $5.077(1.38)$ & $-0.21(-1.02)$ & - & $0.039(0.93)$ \\
\hline $\mathrm{Ce} 3$ & - & $-0.304(-2.02)^{* *}$ & $-0.425(-1.05)$ & $0.465(1)$ & - & $0.401(0.78)$ \\
\hline $\mathrm{Ce} 4$ & - & $0.702(2.17)^{* *}$ & - & - & - & - \\
\hline $\mathrm{Ce} 5$ & - & $-0.332(-2.46)^{* *}$ & - & - & - & - \\
\hline Employment Agriculture(-1) & - & $0.344(0.32)$ & $-3.294(-1.24)$ & - & - & $1.236(1.39)$ \\
\hline Employment Agriculture(-2) & - & $2.584(1.73)^{*}$ & $-0.221(-0.18)$ & - & - & $0.841(1.36)$ \\
\hline
\end{tabular}




\section{Macrothink 1nstinte}

Employment Mining(-1)
Employment Mining(-2)
Employment Manufacturing (-1)
Employment Manufacturing (-2)
Employment Construction(-1)
Employment Construction(-2)
Employment Admin(-1)
Employment Admin(-2)
Employment Trade
Employment Non-agric(-1)
Employment Non-agric(-2)
GVA Agriculture(-1)
GVA Agriculture(-2)
GVA Mining(-1)
GVA Mining(-2)
GVA Manufacturing (-1)
GVA Manufacturing (-2)
GVA Construction(-1)

International Journal of Learning and Development ISSN 2164-4063 2021, Vol. 11, No. 2

\begin{tabular}{|c|c|c|c|c|}
\hline$-1.045(-0.82)$ & $0.887(0.73)$ & - & - & $0.757(0.72)$ \\
\hline $0.444(0.31)$ & $-0.343(-0.3)$ & - & - & $-0.349(-0.41)$ \\
\hline$-1.194(-2.05) * *$ & $-0.6(-0.5)$ & - & - & $-1.195(-2.08) * *$ \\
\hline$-1.112(-0.76)$ & $-0.292(-0.40)$ & - & - & $-0.86(-1.19)$ \\
\hline $0.027(0.02)$ & $-2.3(-0.77)$ & - & - & $-1.177(-0.98)$ \\
\hline$-1.112(-0.76)$ & $-0.874(-0.40)$ & - & - & $-0.484(-0.51)$ \\
\hline$-0.796(-0.57)$ & $0.573(0.44)$ & - & - & $0.790(0.77)$ \\
\hline $1.742(1.26)$ & $0.694(0.51)$ & - & - & $0.44(0.45)$ \\
\hline- & - & - & - & - \\
\hline- & - & - & - & - \\
\hline- & - & - & - & - \\
\hline$-0.007(-0.07)$ & - & $0.101(0.42)$ & - & $0.014(0.09)$ \\
\hline$-0.098(-0.77)$ & - & $0.249(1.31)$ & - & $0.072(0.56)$ \\
\hline $0.423(2.09) * *$ & - & $-0.076(-0.27)$ & - & $-0.046(-0.37)$ \\
\hline $0.216(1.75)$ & - & $-0.162(-0.81)$ & - & $0.091(0.69)$ \\
\hline$-0.133(-1.07)$ & - & $0.028(0.8)$ & - & $0.011(0.18)$ \\
\hline$-0.190(-1.52)$ & - & $-0.034(-0.23)$ & - & $0.039(0.71)$ \\
\hline $0.077(0.81)$ & - & $0.09(0.58)$ & - & $-0.023(-0.17)$ \\
\hline
\end{tabular}




\begin{tabular}{|c|c|c|c|c|c|c|}
\hline GVA Construction $(-2)$ & - & $-0.396(-2.24) * *$ & - & $0.227(1.35)$ & - & $0.046(0.58)$ \\
\hline GVA Admin (-1) & - & $0.695(1.19)$ & - & $-0.112(-0.27)$ & - & $0.194(0.38)$ \\
\hline GVA Admin (-2) & - & $0.496(1.29)$ & - & $-0.594(-1.21)$ & - & $0.285(0.63)$ \\
\hline GVA Trade & - & - & - & - & - & - \\
\hline GVA Non-agric(-1) & - & - & - & - & - & - \\
\hline GVA Non-agric (-2) & - & - & - & - & - & - \\
\hline $\operatorname{GDP}(-1)$ & - & - & - & - & - & - \\
\hline $\operatorname{GDP}(-2)$ & - & - & - & - & - & - \\
\hline Inflation Rate(-1) & - & - & $-0.02(-1.47)$ & $-0.004(-0.32)$ & - & $-0.009(-0.87)$ \\
\hline Inflation Rate(-2) & - & - & $-0.005(-0.67)$ & $-0.011(-0.71)$ & - & $0.0005(0.05)$ \\
\hline WAPLR(Weighted Average Prime Lending Rate)(-1) & - & - & $-0.047(-0.94)$ & $0.086(0.69)$ & - & - \\
\hline WAPLR(Weighted Average Prime Lending Rate)(-2) & - & - & $-0.024(-0.65)$ & $0.031(0.42)$ & - & - \\
\hline Minimum wage (-1) & - & - & $-0.025(-2.77) * * *$ & $-0.023(-0.67)$ & - & - \\
\hline Minimum wage (-2) & - & - & $-0.005(-0.45)$ & $0.015(0.59)$ & - & - \\
\hline Constant & - & $-0.027(-0.57)$ & $0.013(0.57)$ & $0.089(2.46)^{* *}$ & - & $0.001(0.06)$ \\
\hline
\end{tabular}

Source: Author's Analysis of Data collected from the National Bureau of Statistics 


\section{Factors that affected Employment during the Growth period of 1981-2014.}

Arising from the above analysis, the factors that affected employment in Nigeria during the growth period of 1981-2014 under review are as follows: -

\section{GDP / GVA}

Though not significantly so, GDP growth was positively correlated to aggregate employment. However, GVA, in particular sectors were significantly correlated to sectoral employment, either negatively or positively depending on inter-sectoral influences as follows:

(a) Two-year lagged GVA in non-Agricultural sector was significantly positively correlated in generating employment in the Agricultural sector.

(b) One-year lagged GVA in the Manufacturing sector was significantly positively correlated to employment generation in the Mining and Quarrying sector.

(c) One-year lagged GVA in the Agricultural sector was significantly negatively correlated to generating employment in the Mining and Quarrying sector.

(d) Two-year lagged GVA in the Construction sector was significantly negatively correlated in generating employment in the Mining and Quarrying sector.

(e) One-year lagged sectoral output (GVA) in the Mining and Quarrying sector was significantly positively correlated to employment in the Administration and Social Services sector.

(f) Prior-year's sectoral output (GVA) in construction was significantly negatively correlated to employment in the Administration and Social Services sector.

Agriculture Sector: The current level of employment in the Agricultural sector is negatively influenced significantly by the last two years' level of employment in the Agricultural sector. The inter temporal elasticity of employment is -1.94 , meaning that a one per cent change in the past two years' employment in the Agricultural sector results in 1.94 per cent change, in the opposite direction, in this year's level of employment in the Agricultural sector.

Similarly, the growth elasticity of employment with respect to Gross Value Added in the Agricultural sector is -0.13 , and lagged by one year. This means that a one per cent change in Gross Value Added in Agriculture in the previous year results into an opposite change of 0.13 per cent in the current level of employment in the Agricultural sector.

Furthermore, the elasticity of employment in the Agricultural sector with respect to the non-Agricultural Gross Value Added is 0.39, positive and has a lag of 2 years. This means, a one per cent change in the level of Gross Value Added in the non-Agricultural sector in the prior 2 years is accompanied by a change, in the same direction, of 0.39 per cent in current year's employment in the Agricultural sector.

Another significant relationship is that between minimum wage and employment in the Agricultural sector, which has a coefficient of -0.023 and lagged by one year. This implies that a one per cent change in the minimum wage of the previous year is accompanied by a 
change, in the employment level, in the opposite direction, of 0.023 per cent. See table 4.3.1.

Mining and Quarrying Sector: Current employment level in the Mining sector is significantly influenced by the immediate past Gross Value Added in Agricultural sector. More specifically, the growth elasticity of employment in the Mining sector with respect to Gross Value Added in Agriculture is -0.891 and lagged by one year. This means that one percent change in Gross Value Added in Agriculture in the immediate past year is accompanied by a 0.891 per cent change in the employment level this year in the Mining sector in the opposite direction.

Also, current employment in the Mining sector of the Nigerian economy is significantly influenced by the Gross Value Added of the previous year in the Manufacturing sector. Specifically, the employment intensity of growth in the Mining sector with respect to Gross Value Added in the Manufacturing sector of the economy is 1.241, positive and lagged by one year. This means, a one per cent change in the level of Manufacturing Gross Value Added of the immediate past year is accompanied by a 1.241 per cent change in employment in the Mining sector in the same direction.

Furthermore, current employment in the Mining sector of the Nigerian economy in the period under review is significantly influenced by two-year lagged Gross Value Added in the Construction sector. The employment intensity of growth in the Mining sector with respect to Gross Value Added in the Construction sector is -0.447 and lagged by two years. In other words, a one per cent change in prior two years' Gross Value Added in the Construction sector is accompanied by a 0.447 per cent change, in the opposite direction, in employment in the current year in the Mining sector.

In addition, employment in the Mining sector of the economy is significantly affected by the Weighted Average Prime Lending Rate (WAPLR) of the immediate past year. In specific terms, the intensity or coefficient is -0.468 . This implies that a one per cent change in the previous year's WAPLR is associated with a 0.468 per cent change, in the opposite direction, in employment level in the Mining sector of the Nigerian economy. See table 4.3.2.

Manufacturing Sector: Employment in the Manufacturing sector is influenced significantly by the immediate past year's employment level in Agriculture. The coefficient of intensity is -11.133 and lagged by one year. This implies that a one per cent change in the immediate past year's employment in Agriculture is associated with 11.133 per cent change, in the opposite direction, in employment in the Manufacturing sector.

Employment in the Manufacturing sector is also influenced significantly by the immediate past year's employment in the Mining sector. Specifically, the employment intensity of growth in the Manufacturing sector with respect to employment in the Mining sector is 5.134 lagged by one year. This means that a one per cent change in the level of employment in the immediate past year in the Mining sector is accompanied by a 5.134 per cent change, in the same direction, in employment in the Manufacturing sector.

Furthermore, the current level of employment in the Manufacturing sector is significantly affected by the last two years' employment in that sector. The intertemporal employment 
intensity of growth in the Manufacturing sector is -3.044 with a lag of two year. This means that a one per cent change in the level of employment of the past two years in the Manufacturing sector results in a change in the current year employment level by 3.044 per cent, in the opposite direction, in the same (Manufacturing) sector.

Also, current employment level in the Manufacturing sector is influenced significantly by previous year's employment in the Construction sector of the Nigerian Economy. The employment intensity of growth in the Manufacturing sector with respect to employment in the Construction sector is -15.197 lagged by a year. By implication, a one per cent change in last year's employment in the Construction sector of the economy, during the period under review, is accompanied by a 15.197 per cent employment change, in the opposite direction, in the Manufacturing sector.

Furthermore, the current employment level in the Manufacturing sector is significantly influenced by the immediate past year's employment in Administration. The employment intensity of growth in the Manufacturing sector with respect to employment in the Administration sector of the economy is 5.259 lagged by one year. This means a one per cent change in the immediate past year's employment in the Administration sector is accompanied by a 5.259 per cent change, in the same direction, in employment in the Manufacturing sector of the Nigerian economy during the period under review. See table 4.3.3.

Administration and Social Services Sector: Employment in the Administration sector of the Nigerian economy during the period under review is significantly and positively influenced by the level of employment of the past two years in the Agricultural sector of the economy. Specifically, the employment intensity of growth in the Administration sector with respect to employment in the Agricultural sector is 2.584 , lagged by two years. This implies that a one per cent change in the level of employment in the Agricultural sector two prior years is associated with a 2.584 per cent change, in the same direction, in the current level of employment in the Administration sector.

The current level of employment in the Administration sector is also significantly influenced by the immediate past year's employment in the Manufacturing sector. The employment intensity of growth in the Administration sector with respect to prior year's employment in the Manufacturing sector is -1.194. This means that a one per cent change in the employment level of the immediate past year in the Manufacturing sector is accompanied by a 1.194 per cent change, in the opposite direction, in employment in the Administration sector of the economy.

Furthermore, the current level of employment in the Administration sector is significantly and positively influenced by one-year lagged level of Gross Value Added in Mining. The employment intensity of growth in the Administration sector with respect to one-year lagged level of Gross Value Added in the Mining sector is 0.423 and positive. This means, a one per cent change in the level of the immediate past year's Gross Value Added in Mining sector of the economy is accompanied a 0.423 per cent change, in the same direction, in employment in the Administration sector of the economy. 
Also, employment in the Administration sector of the economy is significantly influenced by the level of Gross Value Added in the Construction sector, lagged by two years. The employment intensity of growth in the Administration sector with respect to Gross Value Added in the Construction sector is -0.396 . This means that a one per cent change in the previous two years' Gross Value Added in Construction is accompanied by 0.396 percent change, in the opposite direction, in the employment level of the Administration sector. See table 5 .

Construction Sector: The results cannot be relied upon for policy making, because there is no plausible scenario where the error will continuously be reduced over the years.

Wage Rate: Though not significant at aggregate levels, wage rate was negatively correlated to employment. However, at sectoral levels, wage rate was significantly and negatively correlated with employment in Agriculture, where employment in Agriculture sector moved in opposite direction to previous year's wage rate.

Interest Rate: Just like wage rate, interest rate moved in opposite direction to aggregate employment in the economy during the period under review, but the relationship was not significant. However, it was significant in the Manufacturing, and Mining and Quarrying sectors, where employment moved in opposite directions to one-year lagged interest rates.

Inflation Rate: Also, at the aggregate level, inflation is not a significant negative correlate of employment in the Nigerian economy during the growth period between 1981 and 2014 . However, it was significant in the Manufacturing sector, where employment was negatively correlated to one-year lagged rate of inflation.

Time lag: Time is a significant factor in in moderating, shaping, diminishing or enhancing a phenomenon, like output growth and employment creation. In this case, employment in Agriculture depended, among others, on previous year's wage rate $\left(\mathrm{W}_{\mathrm{t}-1}\right)$ in Agriculture and previous year's Agricultural output (GVA Agriculture ${ }_{t-1}$ ). Prior two years' gross value added in non-agricultural sectors (GVA non-Agriculture ${ }_{t-2}$ ) and prior two years' employment in non-agriculture (Employment non-Agriculture $t_{t-2}$ ) positively stimulated employment in Agriculture, while prior two years' employment in the agriculture sector (Employment Agriculture $_{t-2}$ ) and previous year's gross value added in agriculture (GVA Agriculture t-1 $_{1}$ ) and previous year's wage rate (wage rate $\mathrm{t}_{\mathrm{t}-1}$ ) limit current year's agricultural employment.

In the agricultural sector, this explains the cyclicality in agricultural production, and the long term nature of most agricultural production. For the whole economy, most importantly, this emphasis the need for long-term planning and the use of rolling plans to bridge short term plans.

\section{Recommendations}

Gross value added (GVA), interest rate, wage rate, and inflation rate were significant influencers of sectoral employment, with individual peculiarities. Policy makers should therefore employ these, appropriately, as tools in generating employment intensive aggregate output growths and gross value added in the economy. 
Arising from the significant job creating capacities of the various sectors of the economy and their interdependencies, a framework for Employment-Growth targeting should be constructed to pilot growth in a way to make it create jobs in the various sector and on aggregate level commensurately. This is, also, expected to deliver diversified and inclusive employment commensurate with diversified and inclusive growth.

In the agricultural sector, we found the explanation for the cyclicality in agricultural production, and, hence the need to plan across the life-cycle of agricultural produce. For the whole economy, most importantly, we should embrace long-term planning and use rolling plans to bridge short term plans or budgets.

\section{Conclusion}

In the period of growth between 1981 and 2014 in Nigeria, gross value added (GVA), interest rate, wage rate, inflation rate, and time were significant influencers of sectoral employment, with individual sectoral peculiarities. Policy makers should therefore employ these, appropriately, as tools in generating employment intensive aggregate output growths and sectoral gross value added in the economy. More than ever before, we should employ long-term plans, and also use rolling plans to bridge budgets or short-term plans.

\section{References}

Adeniyi, A. (2019). Economic growth and employment nexus in Nigeria's agricultural and non-agricultural sectors (1981-2014) (PhD Thesis in the Department of Agricultural Economics (in Press)).

Adeniyi, A. (2021). Designing a framework for employment-growth targeting in Nigeria. Journal of Asia Development, 7(1). https://doi.org/10.5296/jad.v7i1.18295

Ajakaiye, O., Jerome, A. T., Nabena, D., \& Alaba, O. A. (2015). Understanding the relationship between growth and employment in Nigeria (No. 2015/124). WIDER Working Paper. https://doi.org/10.35188/UNU-WIDER/2015/013-3

Ajilore, T., \& Yinusa, O. (2011). An analysis of employment intensity of sectoral output growth in Botswana. Southern African Business Review, 15(2), 26-42.

Ajimotokan. O., \& Obi, P. (2016). Government and NLC set up technical committee on minimum wage and pump price of petrol. Back page, Thisday Newspaper, May 26.

Baah-Boateng, W. 2013. Determinants of Unemployment in Ghana. African Development Review, 21(4), 385-399. https://doi.org/10.1111/1467-8268.12037

Buhari, M. (2016). 27 States have difficulties paying salaries. Punch Newspapers, July 24.

Central Bank of Nigeria (CBN). 2015. 2014 Annual Report and Statement of Accounts.

Dopke, J. (2001). The Employment Intensity of Growth in Europe. Kieler Arbeitspapiere. No. 1021. Retrieved from http://hdl.handle.net/10419/17746.

Eme, O. I., \& Ugwu P hD, S. C. (2011). Governors and the new minimum wage act: 
implications for state-labour relations in Nigeria. Arabian Journal of Business and Management Review, 1(3).

Engle, R. F., \& Granger, C. W. (1987). Co-Integration and Error Correction: Representation, Estimation and Testing. Econometrica, 55(2), 251-276. https://doi.org/10.2307/1913236

Felipe, J., \& McCombie, J. S. L. (2015). Aggregate Production Function and the Measurement of Technical Change 'Not Even Wrong'. Edward Elgar Publishing Ltd.

Hansen, P., \& King, A. (1996). The determinants of health care expenditure: a cointegration

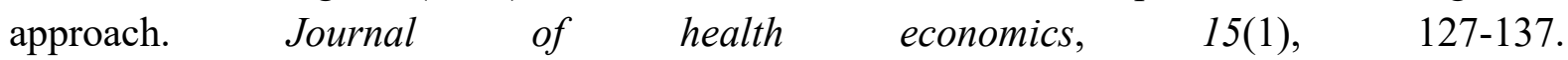
https://doi.org/10.1016/0167-6296(95)00017-8

ILO. (1970). General Survey of the Reports of the Minimum Wage Fixing Convention. No. 131, and the Minimum Wage Fixing Recommendations No. 135. International Labour Conference, 103rd Session, 2014. ILC.103/III/1B.

Johansen, S. (1995). Likelihood-based inference in cointegrated vector autoregressive models. Oxford University Press on Demand. Oxford: Clarendon Press. https://doi.org/10.1093/0198774508.001.0001

Koop, G., \& Quinlivan, R. (2005). Analysis of economic data. John Wiley \& Sons.

Malunda, D. (2013). The employment intensity of non-agricultural growth in Rwanda: analysing the links between growth, employment, and productivity in Rwanda.

Mkhize, N. I. (2015). The sectorial employment intensity of growth in South Africa, 2000-2012 (Doctoral dissertation).

Nangale, G. (2012, September). The role of the state in economic development: Employment challenges in Eastern Africa-the case of Tanzania. In Proceeding of the Friedrich Ebert Stiftung (FES) Eastern African Conference on Employment Policies in Nairobi, Kenya. Nairobi: Friedrich Ebert Stiftung.

NBS. (2015a). Nigerian Gross Domestic Product Report, Quarter Two. Issue 6.

NBS. (2015a). Unemployment / Under-employment Watch.

NBS. (2016). Post GDP Rebasing Revision 1981 - 2010. July 18.

Nigeria Employers' Consultative Association (NECA). 2003. Inter Industrial Survey.

Sodipe, O. A., \& Ogunrinola, I. O. (2011). Employment and economic growth nexus in Nigeria. International Journal of Business and Social Science, 2(11).

Solow, R. M. (1966). Review of Capital and Growth. American Economic Review, December, 1257-60.

Soludo, C. C. (2015). PDP handed Nigeria over in a better state than it met Nigeria. The Whistler, December 20.

Song, H., \& Witt, S. F. (2000). Tourism demand modelling and forecasting. Modern 
econometric approaches. Oxford, Pergamon.

Soto, R. (2009). Dollarisation, Economic Growth and Employment. Economic Letters, 105(1), 42-45. https://doi.org/10.1016/j.econlet.2009.05.012

Stock, J. H., \& Watson, M. W. (2017). Introduction to Econometrics (Update, 3rd ed.). Pearson Education.

Temitope, L. A. L. (2013). Does Economic Growth Lead Employment in South Africa? Journal of Economics and Behavioural Studies, 5(6), 336-345. https://doi.org/10.22610/jebs.v5i6.409

Temitope, L. A. L. (2014). Empirical Analysis of Employment Elasticity of Growth in Botswana. Mediterranean Journal of Social Science, 5(2), 171-180.

\section{Copyright Disclaimer}

Copyright for this article is retained by the author(s), with first publication rights granted to the journal.

This is an open-access article distributed under the terms and conditions of the Creative Commons Attribution license (http://creativecommons.org/licenses/by/4.0/). 